\title{
THE INFLUENCE OF ELECTRON BEAM IRRADIATION DOSE AND POLYFUNCTIONAL MONOMERS CONCENTRATIONS ON THE PHYSICO-MECHANICAL CHARACTERISTICS OF THE EPDM/HPDE BLENDS
}

\author{
INFLUENTA DOZEI DE IRADIERE CU ELECTRONI ACCELERATI ŞI A CONCENTRATIEI DE MONOMER \\ POLIFUNCTIONAL ASUPRA CARACTERISTICILOR FIZICO-MECANICE ALE UNOR AMESTECURI EPDM/HPDE
}

\author{
Maria Daniela STELESCU ${ }^{1 *}$, Elena MANAILA², Gabriela CRACIUN ${ }^{2}$, Dana GURAU ${ }^{1}$ \\ ${ }^{1}$ National Research \& Development Institute for Textiles and Leather, Division: Leather and Footwear Research Institute, 93 lon Minulescu St.,
} 031215, Bucharest, Romania, e-mail: dmstelescu@yahoo.com

${ }^{2}$ National Institute for Laser, Plasma and Radiation Physics, Electron Accelerators Laboratory, \#409 Atomistilor St., 077125 Magurele, Romania, e-mail: elena.manaila@inflpr.ro; gabriela.craciun@inflpr.ro

\section{THE INFLUENCE OF ELECTRON BEAM IRRADIATION DOSE AND POLYFUNCTIONAL MONOMERS CONCENTRATIONS ON THE PHYSICO-MECHANICAL CHARACTERISTICS OF THE EPDM/HPDE BLENDS}

ABSTRACT. The paper presents a study on the improvement of physico-mechanical characteristics of blends containing ethylene-propylene-terpolymer (EPDM) and high density polyethylene (HDPE) by electron beam (EB) irradiation and polyfunctional monomers (PFMs) addition. Dependence of physico-mechanical properties on irradiation dose was determined from a dose range of $0 \mathrm{kGy}$ to $200 \mathrm{kGy}$. As PFMs, trimethylol-propane-trimethacrylate (TMPT) and zinc-diacrylate (ZDA) were used. The obtained results show that EB irradiation produces EPDM crosslinking and improves the characteristics of the mixture. To reduce the EB irradiation dose, PFMs were introduced.

KEY WORDS: ethylene-propylene terpolymer rubber, high density polyethylene, polyfunctional monomers, electron beam, physico-mechanical characteristics

\section{INFLUENTA DOZEI DE IRADIERE CU ELECTRONI ACCELERATI ŞI A CONCENTRATIEI DE MONOMERI POLIFUNCTIONALI ASUPRA CARACTERISTICILOR FIZICO- MECANICE ALE UNOR AMESTECURI EPDM/HDPE}

REZUMAT. Lucrarea de faţă prezintă un studiu asupra îmbunătăţirii caracteristicilor fizico-mecanice ale unor amestecuri pe bază de terpolimeri etilenă-propilenă (EPDM) şi polietilenă de înaltă densitate (HDPE) prin iradiere cu electroni acceleraţi (EA) şi prin adăugarea de monomeri polifuncţionali (MPF). Dependenţa proprietăţilor fizico-mecanice de doza de iradiere s-a studiat în domeniul 0-200 kGy. Ca MPF s-au utilizat trimetilol-propan-trimetacrilat (TMPT), respectiv zincdiacrilat (ZDA). Rezultatele obţinute arată că iradierea cu EA produce reticularea EPDM şi îmbunătăţeşte caracteristicile amestecului. Introducerea MPF ajută la scăderea dozei de iradiere cu EA.

CUVINTE CHEIE: cauciuc terpolimer etilenă-propilenă, polietilenă de înaltă densitate, monomeri polifuncţionali, electroni acceleraţi, caracteristici fizico-mecanice

\section{L'INFLUENCE DE LA DOSE D'IRRADIATION PAR FAISCEAU D'ÉLECTRONS ET DE LA CONCENTRATION EN MONOMÈRES POLYFONCTIONNELS SUR LES} PROPRIÉTÉS PHYSICO-MÉCANIQUES DES MÉLANGES EPDM/PEHD

RÉSUMÉ. Cet article présente une étude sur l'amélioration des propriétés physico-mécaniques des mélanges à base de terpolymères d'éthylène-propylène (EPDM) et un polyéthylène haute densité (PEHD) en appliquant l'irradiation par un faisceau d'électrons (EA), et en ajoutant des monomères polyfonctionnels (MPF). La dépendance des propriétés physico-mécaniques de la dose d'irradiation a été étudiée dans l'interval 0-200 kGy. Comme MPF on a utilisé triméthacrylate de triméthylolpropane (TMPT) et diacrylate de zinc (ZDA). Les résultats montrent que l'irradiation par EA cause réticulation des EPDM et améliore les caractéristiques du mélange. En ajoutant des MPF, la dose d'irradiation par EA diminue.

MOTS CLÉS: caoutchouc terpolymère d'éthylène-propylène, polyéthylène haute densité, monomères polyfonctionnels, faisceau d'électrons, caractéristiques physico-mécaniques

\section{INTRODUCTION}

Thermoplastic elastomeric materials based on blends of ethylene-propylene-diene terpolymers (EPDM) and polyolefins combine the technical advantages in processing of thermoplastics with the excellent physical properties of elastomers, thus gaining significant importance in a variety of applications, especially in the automotive industry, electrical cables and wires, packing materials, footwear, etc. [1].

\section{INTRODUCERE}

Materialele elastomerice termoplastice pe bază de amestecuri de terpolimeri etilenă-propilenă (EPDM) şi poliolefine combină avantajele tehnice ale prelucrării materialelor termoplastice cu proprietăţile fizice excelente ale elastomerilor, fapt de importanţă semnificativă într-o serie de aplicaţii din industriile de automobile, cabluri electrice şi fire, ambalaje, încălţăminte etc. [1]. 
The paper presents a study on the improvement of physico-mechanical characteristics of blends containing EPDM and high density polyethylene (HDPE) by electron beam (EB) irradiation and polyfunctional monomers (PFMs) addition.

Modification of thermoplastic and rubbery materials by electron beam radiation is a potential method for development of new polymers and composites. Irradiation of polymeric materials results in grafting and subsequently formation of a three dimensional network through the union of generated macro radicals [2]. The main advantages of irradiation compared to other methods used in elastomeric, plastic or elastic-plastic materials processing, in order to improve their properties are: (a) it can be directly applied to the finished product, offering dimensional stability, (b) due to ionizing radiation properties, certain characteristics can be improved or products with unique properties can be obtained, which cannot be achieved using other methods, (c) by using high power accelerators volatile organic compound emissions are reduced, energy is better used and a more exact control of the process is obtained [3-5]. Research papers have been published suggesting that appropriate polyfunctional monomers (PFMs), also called coagents, added in polymer matrix could be used to obtain desired physical properties of the blend at lower irradiation doses. Coagents are multifunctional organic molecules which are highly reactive towards free radicals. Previous studies [5-6] show that the most efficient PFMs in the case of EPDM were trimethylolpropane-trimethacrylate (TMPT) and zinc-diacrylate (ZDA). The reaction can be depicted as a two-step process: (1) rapid initial polymerization of the polyfunctional monomer and (2) reaction of the polymerized polyfunctional monomer with EPDM chains which "ties" the latter with the former to form a crosslinked EPDM-polyfunctional monomer network [7].

\section{EXPERIMENTAL}

The following raw materials were used: EPDM rubber Nordel 4760 (Mooney viscosity is $70 \mathrm{ML}_{1+4}$ at $120^{\circ} \mathrm{C}, 70 \%$ ethylene content, 5-ethylidenenorbornene (ENB) 4.9 wt \%, density $0.88 \mathrm{~g} / \mathrm{cm}^{3}, 10 \%$ crystalline degree), HDPE Hostalen GC 7260 (density $0.962 \mathrm{~g} / \mathrm{cm}^{3}$
Lucrarea prezintă un studiu asupra îmbunătăţirii caracteristicilor fizico-mecanice ale amestecurilor pe bază de cauciuc etilenă-propilenă (EPDM) şi polietilenă de înaltă densitate (HDPE) prin iradiere cu electroni acceleraţi (EA) şi prin adăugarea de monomeri polifuncţionali (MPF).

Modificarea materialelor termoplastice şi a cauciucurilor prin iradiere cu EA este o metodă capabilă să dezvolte noi materiale polimerice şi compozite. Iradierea materialelor polimerice produce grefarea şi ulterior formarea unei reţele tridimensionale prin unirea macroradicalilor generaţi [2]. Principalele avantaje ale iradierii comparativ cu alte metode folosite pentru prelucrarea materialelor elastomerice, plastice sau elasto-plastice în scopul îmbunătăţirii proprietăţilor lor sunt: (a) se poate aplica direct pe produsul finit, oferind stabilitate dimensională, (b) proprietăţile şi caracteristicile specifice ale radiaţiilor ionizante conduc la obţinerea de produse cu proprietăţi îmbunătăţite şi unice, care în alte condiţii şi prin alte metode nu pot fi atinse, (c) utilizând acceleratoare de electroni de mare putere, emisiile de compuşi organici volatili sunt reduse, energia este utilizată mai eficient, iar procesul este mai bine controlat [3-5]. Literatura de specialitate arată că adăugarea de monomeri polifuncţionali (MPF) adecvaţi, numiţi şi coagenţi, conduce la obţinerea proprietăţilor fizice dorite la doze de iradiere scăzute. Coagenţii sunt molecule organice multifuncţionale, extrem de reactive faţă de radicalii liberi. Studiile anterioare $[5,6]$ au arătat că cei mai eficienţi MPF pentru EPDM au fost trimetilol-propantrimetacrilat (TMPT) şi zinc-diacrilat (ZDA). Reacţia poate fi descrisă ca un proces în două etape: (1) polimerizarea iniţială rapidă a monomerului polifuncţional şi (2) reacţia monomerului polifuncţional polimerizat cu lanţurile de EPDM cu formarea unei reţele reticulate de EPDM-monomer polifuncţional [7].

\section{PARTEA EXPERIMENTALĂ}

Materiile prime utilizate au fost următoarele: cauciuc EPDM de tip Nordel 4760 (vâscozitate Mooney $70 \mathrm{ML}_{1+4}$ la $120^{\circ} \mathrm{C}$, conţinut de etilen $70 \%$, 5-etilidenenorbornenă (ENB) 4,9 wt \%, densitate $0,88 \mathrm{~g} / \mathrm{cm}^{3}$, gradul cristalin $10 \%$ ), HDPE de tip Hostalen GC 7260 (densitate $0,962 \mathrm{~g} / \mathrm{cm}^{3}$ şi 
and a melting point of $\left.72^{\circ} \mathrm{C}\right)$, compatibilization agent maleinized polyethylene (PE-g-AM) Polybond 3009 (1\% maleic anhydride, density $0.95 \mathrm{~g} / \mathrm{cm}^{3}$, melting point of $127^{\circ} \mathrm{C}$ ), polyfunctional monomer trimethylol-propanetrimethacrylate (TMPT) Luvomaxx TMPT DL 75 (22\% percentage of ash, $\mathrm{pH} 9.2$, density $1.36 \mathrm{~g} / \mathrm{cm}^{3}, 75.63 \%$ active ingredient), polyfunctional monomer zincdiacrylate (ZDA) Luvomaxx ZDA GR 75 (density 1.23 $\mathrm{g} / \mathrm{cm}^{3}$ ), antioxidant pentaerythritol tetrakis(3-(3,5-ditert-butyl-4-hydroxyphenyl) propionate Irganox 1010 (melting point of $40^{\circ} \mathrm{C}, 98 \%$ active ingredient).

Blends were prepared by melt blending technique, on a laboratory electrically heated roller mill equipped with a cooling system. The working parameters were: friction $1: 1.1$ and temperature $125-140^{\circ} \mathrm{C}$. The mixing sequence involved first introducing thermoplastic polymer HDPE (3-4 min), and, after melting, the compatibilizing agent (PE-g-MA, 1-2 $\mathrm{min}$ ) was added. Then, EPDM rubber was incorporated (3-4 min). When a homogeneous blend was obtained, the antioxidant (Irganox 1010) was introduced (1-2 min). For the formulation with PFMs, TMPT or ZDA were added and the mixing process was continued for about $3 \mathrm{~min}$. Finally, the composition was homogenized for $5 \mathrm{~min}$ to obtain a sheet about $2 \mathrm{~mm}$ thick. Test specimens were obtained by compression molding at $160^{\circ} \mathrm{C}$ and a pressure of $150 \mathrm{MPa}$ for 5 min using an electrical press. The plates were then cooled to room temperature under pressure.

For EPDM/HDPE blends preparation, the blend constituents were added in the following amounts: 300g HDPE, 100g EPDM, 20g PE-g-AM and 2g Irganox 1010 ( $\left.T_{25} \mathrm{O}\right), 200 \mathrm{~g}$ HDPE, 200g EPDM, 20g PE-g-AM and $2 \mathrm{~g}$ Irganox $1010\left(\mathrm{~T}_{50} \mathrm{O}\right), 100 \mathrm{~g}$ HDPE, 300g EPDM, 20g PEg-AM and 2g Irganox 1010 ( $\left.T_{75} \mathrm{O}\right), 400 \mathrm{~g}$ EPDM and $2 \mathrm{~g}$ Irganox $1010\left(\mathrm{~T}_{100} \mathrm{O}\right)$.

For EPDM/HDPE/TMPT preparation, the blend constituents were added in the following sequence and amounts: 300g HDPE, 100g EPDM, 20g PE-g-AM, $2 \mathrm{~g}$ Irganox 1010 and $3 \mathrm{phr}$ (parts per 100 parts of rubber) $\operatorname{TMPT}\left(\mathrm{T}_{25} \mathrm{OT}_{3}\right), 6 \mathrm{phrTMPT}\left(\mathrm{T}_{25} \mathrm{OT}_{6}\right), 9 \mathrm{phr} \mathrm{TMPT}\left(\mathrm{T}_{25} \mathrm{OT}_{9}\right)$, and 12 phr TMPT $\left(\mathrm{T}_{25} \mathrm{OT}_{12}\right)$ respectively.

For EPDM/HDPE/ZDA preparation, the blend constituents were added in the following sequence and amounts: 300g HDPE, 100g EPDM, 20g PE-g-AM, 2g Irganox 1010 and 3 phr ZDA $\left(\mathrm{T}_{25} \mathrm{OZ}_{3}\right), 6$ phr ZDA $\left(\mathrm{T}_{25} \mathrm{OZ}_{6}\right)$, $9 \mathrm{phrZDA}\left(\mathrm{T}_{25} \mathrm{OZ}_{9}\right)$, and $12 \mathrm{phr} Z \mathrm{DA}\left(\mathrm{T}_{25} \mathrm{OZ}_{12}\right)$. punct de topire $72^{\circ} \mathrm{C}$ ), agent de compatibilizare polietilenă maleinizată (PE-g-AM) de tip Polybond 3009 ( $1 \%$ anhidridă maleică, densitate $0,95 \mathrm{~g} / \mathrm{cm}^{3}$, punct de topire $127^{\circ} \mathrm{C}$ ), monomer polifunç̧ional trimetilol-propantrimetacrilat (TMPT) de tip Luvomaxx TMPT DL 75 (procent de cenuşă $22 \%$, pH 9,2, densitate $1,36 \mathrm{~g} / \mathrm{cm}^{3}$, ingredient activ $75,63 \%$ ), monomer polifuncţional zinc-diacrilat (ZDA) de tip Luvomaxx ZDA GR 75 (densitate $1,23 \mathrm{~g} / \mathrm{cm}^{3}$ ), antioxidant pentaeritritol tetrakis(3-(3,5-di-terţ-butil-4hidroxifenil)propionat de tip Irganox 1010 (punct de topire $40^{\circ} \mathrm{C}, 98 \%$ ingredient activ).

Amestecurile s-au realizat prin tehnica amestecării în topitură, pe un valţ de laborator cu încălzire electrică prevăzut cu sistem de răcire. Parametrii de lucru au fost: fricţia 1:1,1 şi temperatura de lucru $125-140^{\circ} \mathrm{C}$. Ordinea de introducere a ingredientelor: prima dată are loc introducerea polimerului termoplastic HDPE (3-4 min) şi, după topirea acestuia, adăugăm agentul de compatibilizare (PE-g-MA, 1-2 min). Apoi încorporăm cauciucul EPDM (3-4 min). După omogenizarea acestuia în amestec, s-a introdus antioxidantul (Irganox 1010, 1-2 min). Pentru variantele de amestecuri cu MPF, s-au adăugat TMPT, respectiv ZDA şi s-a continuat procesul de amestecare timp de încă aproximativ 3 min. La final, amestecurile s-au omogenizat timp de cca 5 min şi amestecurile au fost scoase de pe valţ sub formă de foi cu grosimea de $2 \mathrm{~mm}$. Epruvetele s-au obţinut prin modelare prin compresie la $160^{\circ} \mathrm{C}$ şi $150 \mathrm{MPa}$ timp de $5 \mathrm{~min}$ cu ajutorul unei prese electrice. Plăcile astfel obţinute $\mathrm{s}$-au răcitsub presiune la temperatura camerei.

Pentru obţinerea amestecurilor EPDM/HDPE, constituenţii amestecului, s-au adăugat în următoarele cantităţi: 300g HDPE, 100g EPDM, 20g PE-g-AM şi $2 \mathrm{~g}$ Irganox 1010 ( $\left.T_{25} \mathrm{O}\right)$, 200g HDPE, 200g EPDM, 20g PE-gAM şi 2g Irganox $1010\left(T_{50} \mathrm{O}\right), 100 \mathrm{~g} H D P E, 300 \mathrm{~g}$ EPDM, 20g PE-g-AM şi 2g Irganox $1010\left(\mathrm{~T}_{75} \mathrm{O}\right), 400 \mathrm{~g}$ EPDM şi $2 \mathrm{~g}$ Irganox $1010\left(T_{100} O\right)$.

Pentru prepararea amestecurilor EPDM/HDPE/ TMPT, ingredientele amestecului s-au adăugat în următoarele secvenţe şi cantităţi: 300g HDPE, 100g EPDM, 20g PE-g-AM, 2g Irganox 1010 şi 3 phr (părţi la 100 părţi de cauciuc) TMPT $\left(\mathrm{T}_{25} \mathrm{OT}_{3}\right), 6 \mathrm{phr}$ TMPT $\left(\mathrm{T}_{25} \mathrm{OT}_{6}\right), 9 \mathrm{phr}$ TMPT $\left(\mathrm{T}_{25} \mathrm{OT}_{9}\right)$, respectiv $12 \operatorname{phrTMPT}\left(\mathrm{T}_{25} \mathrm{OT}_{12}\right)$.

Pentru prepararea amestecurilor EPDM/HDPE/ZDA, ingredientele amestecului s-au adăugat în următoarele secvenţe şi cantităţi: 300g HDPE, 100g EPDM, 20g PE-gAM, 2g Irganox 1010 şi 3 phr ZDA $\left(T_{25} \mathrm{OZ}_{3}\right), 6$ phr ZDA $\left(\mathrm{T}_{25} \mathrm{OZ}_{6}\right), 9 \mathrm{phrZDA}\left(\mathrm{T}_{25} \mathrm{OZ}_{9}\right)$, şi $12 \mathrm{phrZDA}\left(\mathrm{T}_{25} \mathrm{OZ}_{12}\right)$. 
The samples were packed in a polyethylene film and were irradiated at irradiation doses of 50, 100, 150 and 200 kGy, respectively, in the ALIN-10 electron beam accelerator under atmospheric conditions and at room temperature of $25^{\circ} \mathrm{C}$. The ALIN-10 electron accelerator was built in Romania, at the National Institute for Lasers, Plasma and Radiation Physics, Electron Accelerator Laboratory in Bucharest. The optimum values of the $E B$ peak current $I_{E B}$ and $E B$ energy $E_{E B}$ to produce maximum output power $P_{E B}$ for a fixed pulse duration ${ }_{\mathrm{EB}}$ and repetition frequency $\mathrm{f}_{\mathrm{EB}}$ are as follows: $\mathrm{E}_{\mathrm{EB}}=6.23 \mathrm{MeV} ; \mathrm{I}_{\mathrm{EB}}=75 \mathrm{~mA} ; \mathrm{P}_{\mathrm{EB}}=164 \mathrm{~W}\left(\mathrm{f}_{\mathrm{EB}}=100 \mathrm{~Hz}\right.$, $\mathrm{EB}=$ $3.5 \mathrm{~s})$. The EB effects are related to the absorbed dose (D), expressed in Gray or $\mathrm{kg}^{-1}$, and absorbed dose rate (D*), expressed in Gy s $\mathrm{s}^{-1} \mathrm{~kg}^{-1} \mathrm{~s}^{-1}$.

The tensile properties of samples were determined using a Schopper tensile tester with a nominal rate of the traverse of the moving grip of 460 $\mathrm{mm} / \mathrm{min}$. The tensile strength was carried out according to the conditions described in ISO 37/2012, on dumbbell shaped specimens. Tearing strength tests were carried out using angular test pieces (type II) according to SR EN $12771 / 2003$. The hardness, in units of Shore A was measured using a hardness tester according to ISO 7619-1/2011. The elasticity was evaluated with a Schob test apparatus using $6 \mathrm{~mm}$ thick samples according to ISO 4662/2009.

\section{RESULTS AND DISCUSSIONS}

\section{The Influence of EB Irradiation Dose on Physico- Mechanical Characteristics of EPDM/HDPE Blends}

The effects of ionizing radiation on polymers have been investigated by many researchers $[8,9]$ over the past few decades. Among the effects is that high energy irradiation causes crosslinking, grafting and degradation in polymers. These reactions are reported to follow the free radical mechanism. Elastomer crosslinking by means of EB is done without heating and in the absence of vulcanization agents. Ionizing radiation produces an excitation of polymer molecules. The energies associated with the excitation are dependent on the absorbed dose of electrons. The interaction results in formation of free radicals formed by dissociation of molecules in the excited state or by
Probele au fost învelite în film de polietilenă şi iradiate cu 50, 100, 150, respectiv 200 kGy utilizând acceleratorul de electroni ALIN-10 la temperatura de $25^{\circ} \mathrm{C}$ şi presiune atmosferică. Acceleratorul de electroni ALIN-10 a fost construit în Laboratorul Acceleratori de Electroni din Institutul Naţional pentru Fizica Laserilor Plasmei şi Radiaţiei, Bucureşti, România. Valorile optime pentru curentul de vârf $\mathrm{I}_{\mathrm{EA}}$ şi energia $E_{E A}$ ale electronilor acceleraţi pentru care se obţine puterea maximă de fascicol $P_{E A}$ pe o durată fixă a pulsului ${ }_{E A}$ şi o frecvenţă de repetiţie $f_{E A}$ sunt următoarele: $E_{E A}=6.23$ $\mathrm{MeV} ; \mathrm{I}_{\mathrm{EA}}=75 \mathrm{~mA} ; \mathrm{P}_{\mathrm{EA}}=164 \mathrm{~W}\left(\mathrm{f}_{\mathrm{EA}}=100 \mathrm{~Hz},_{E A}=3,5 \mathrm{~s}\right)$. Efectele electronilor acceleraţi sunt legate de doza de iradiere (D), exprimată în Gray sau J kg-1, şi debitul dozei de iradiere ( $\left.D^{*}\right)$, exprimat în Gy s $\mathrm{s}^{-1} \mathrm{sau} \mathrm{J} \mathrm{kg}^{-1} \mathrm{~s}^{-1}$.

Proprietăţile de tracţiune ale probelor s-au determinat folosind un echipament de tracţiune de tip Schopper la o viteză de testare de $460 \mathrm{~mm} / \mathrm{min}$. Rezistenţa la rupere $\mathrm{s}$-a determinat în acord cu prevederile ISO 37/2012, pe epruvete în formă de halteră. Determinarea rezistenţei la sfâşiere s-au realizat folosind epruvete de testare unghiulare (tip II), conform prevederilor SR EN 12771/2003. Duritatea în grade Shore A s-a măsurat utilizând un durometru în acord cu prevederile ISO 7619-1/2011. Elasticitatea a fost evaluată o maşină de tip Schob, pe probe având grosimea de 6 mm, în concordanţă cu prevederile ISO 4662/2009.

\section{REZULTATE ŞI DISCUTII}

\section{Influenţa dozei de EA asupra caracteristicilor fizico- mecanice ale amestecurilor EPDM/HDPE}

Efectele radiaţiilor ionizante asupra polimerilor au fost investigate de către mulţi cercetători $[8,9]$ în ultimele decenii. Dintre acestea remarcăm reticularea, grefarea şi degradarea. Despre toate acestea s-a raportat că se desfăşoară prin mecanismul radicalilor liberi. Reticularea elastomerilor prin intermediul EA se realizează fără încălzire şi în absenţa agenţilor de vulcanizare. Radiaţiile ionizante produc excitarea moleculelor de polimer. Energiile asociate cu fenomenul de excitare moleculară sunt dependente de doză absorbită a electronilor acceleraţi. Interacţiunile conduc la formarea de radicali liberi din disocierea moleculelor în starea excitată sau din interacţiunea 
interaction of molecular ions. The free radicals or molecular ions can react by connecting the polymer chains directly or initiating grafting reactions (Figure 1). In Figure 1, "the polymer" can be EPDM, HDPE or PE-gAM (Figure $2 \mathrm{a}-\mathrm{c}$ ). ionilor moleculari. Radicalii liberi sau ionii moleculari pot reacţiona prin conectarea directă a lanţurilor polimerice sau iniţiind reacţii de grefare (Figura 1). În Figura 1, "polimerul" poate fi EPDM, HDPE sau PE-g-AM (Figura $2 \mathrm{a}-\mathrm{c}$ ).

(1) Polymer/Polimer (PH) $\underset{\text { iradiere cu EA }}{\stackrel{\text { EB irradiations }}{\longrightarrow}} \mathrm{PH}^{*}$ (excited state)/(stare de excitatiie)

(2) $\mathrm{PH}^{*} \longrightarrow P H^{+}$(positive ion of polymer) /(ion pozitiv al polimerului) $+1 e^{-}$(electron)

(3) $\mathrm{PH}^{*} \longrightarrow P^{\bullet}$ (free radical of polymer)/(radical liber al polimerului) $+H^{\bullet}$ (hydrogen radical)/(radical al hidrogenului)

(4) $\mathrm{PH}^{+}+\mathrm{PH} \longrightarrow \mathrm{P}^{\bullet}+\mathrm{PH}_{2}^{+}$(radical ion of polymer)/(ion radical al polimerului)

(5) $\mathrm{P}^{\bullet}+\mathrm{PH}_{2}^{+}+1 e^{-} \longrightarrow \mathrm{P}-\mathrm{P}$ (crosslinked polymer) $/($ polimer reticulat)

(6) $P_{1} H^{*}+P_{2} H \longrightarrow P_{1} H+P_{2} H^{*}$ (energy transfer)/(transfer de energie)

(7) $\mathrm{H}^{\bullet}+\mathrm{PH} \longrightarrow \mathrm{P}^{\bullet}+\mathrm{H}_{2}$

Figure 1. Mechanism for electron beam curing

Figura 1. Mecanism de reticulare cu electroni acceleraţi<smiles>C[C@@H]1CCCCC1(C)C</smiles>

high-density polyethylene, HDPE polietilenă de înaltă densitate, HDPE

a)

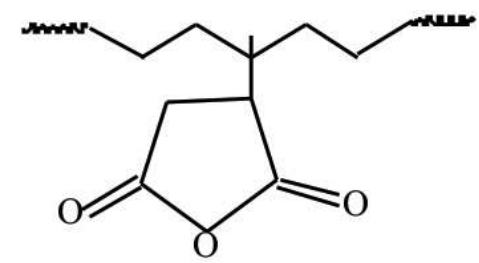

maleinized polyethylene, PE-g-AM polietilena maleinizata, PE-g-AM

b)

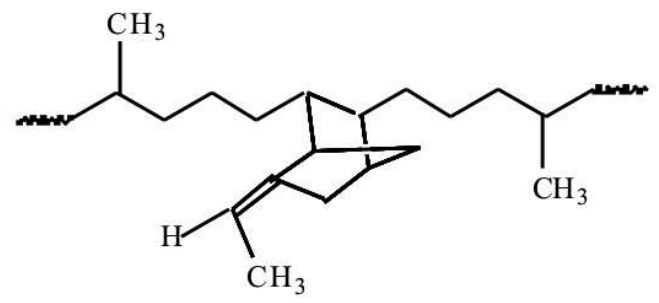

ethylene-propylene elastomers, EPDM elastomeri etilena-propilena, EPDM

c)

Figure 2. Chemical structure of the "polymers" used

Figura 2. Structura chimică a "polimerilor" utilizaţi 
Figures 3-5 and Table 1 present the physicomechanical properties of EPDM/HDPE blends for different compositions and irradiation doses. It can be noticed that with the increase of the amount of HDPE in blends, there is a significant, but non uniform, increase of hardness, $100 \%$ elastic modulus, tensile strength, residual elongation and tear strength and a decrease in elasticity and elongation at break. This indicates that the properties of mixtures depend on the characteristics of the two phases and the mixtures are only partially miscible. By irradiating the samples with different doses of EB, it is observed that, for the $T_{25} \mathrm{O}$ sample, the elongation at break initially increases and then decreases sharply with the irradiation dose, as compared to the results obtained for the other samples which are significantly reduced by the increase of irradiation dose. The initial increase in elongation at break may be due to increase in the interfacial interaction, which eliminates the possibility of formation and propagation of crack at interfaces during stretching. With the increase of irradiation dose, cross-linking reactions occur (see reaction 5 from Figure 1) with the formation of links between macromolecules that reduce macromolecular slipping of layers, thus reducing elongation at break. Also, because of these cross-linking reactions, an increase of $100 \%$ elastic modulus occurs. Tensile strength and tearing strength have the tendency to increase up to a maximum point with EB dose increasing, after showing a slight decrease. This might be due to the degradation taking place at the same time with EPDM and HDPE vulcanization or degree of crystallization decrease by irradiation. However, given the data obtained for $100 \%$ elastic modulus strain, we can deduce that these do not necessarily indicate the elastomer degradation at high irradiation doses, but it can be due to the occurrence of excessive crosslinking in EPDM chain, which in turn produced a brittle material. The irradiation dose of $100 \mathrm{kGy}$ can be considered optimal to get the best features. $\mathrm{T}_{25} \mathrm{O}$ mixture was selected to test the influence of PFMs on the characteristics of mixtures because it shows optimal properties that allow the use of the obtained materials for the development of products such as:
În Figurile 3-5 şi Tabelul 1 sunt prezentate caracteristicile fizico-mecanice ale amestecurilor EPDM/HDPE pentru diferite compoziţii şi doze de iradiere. Se observă că, odată cu creşterea cantităţii de HDPE în amestecuri, are loc o creştere semnificativă, dar neuniformă, a durităţii, modulului la o alungire de $100 \%$, rezistenţei la rupere, alungirii remanente şi rezistenţei la sfâşiere şi o scădere a elasticităţii şi alungirii la rupere. Acest lucru indică faptul că proprietăţile amestecurilor depind de caracteristicile celor două faze şi că amestecurile sunt doar parţial miscibile. Prin iradierea probelor cu diferite doze de EA, se observă că, pentru proba $T_{25} \mathrm{O}$, alungirea la rupere creşte iniţial, după care descreşte brusc cu doza de iradiere, comparativ cu celelalte probe pentru care scade semnificativ cu creşterea dozei de iradiere. Creşterea iniţială a alungirii la rupere poate fi datorată creşterii interaç̧iunii interfaciale, ceea ce elimină posibilitatea formării şi propagării fisurilor interfeţelor în timpul întinderii. La creşterea dozei de iradiere au loc reacţii de reticulare (vezi reacţia 5 din Figura 1) cu formarea de legături între macromolecule care reduc alunecarea straturilor macromoleculare unele faţă de altele, reducând astfel alungirea la rupere. Tot datorită acestor reacţii de reticulare are loc şi creşterea modulului la o alungire de $100 \%$. Rezistenţa la rupere şi rezistenţa la sfâşiere au tendinţa de a creşte cu creşterea dozei de EA până la un punct de maxim, după care prezintă o scădere uşoară. Acest lucru se poate datora procesului de degradare care poate avea loc în acelaşi timp cu vulcanizarea sau scăderea gradului de cristalizare al EPDM şi HDPE prin iradiere. Totuşi, având în vedere datele obţinute pentru modulul de elasticitate $100 \%$, se poate deduce că acestea nu indică neapărat degradarea elastomerul la doze mari de iradiere, dar poate fi cauzată de apariţia reticulării excesive în lanţul de EPDM, care, la rândul său, a produs o fragilitate a materialului. Doza optimă de iradiere poate fi considerată cea de 100 kGy, deoarece a condus la obţinerea celor mai bune caracteristici. Amestecul $\mathrm{T}_{25} \mathrm{O}$ a fost selectat pentru testarea influenţei MPF asupra caracteristicilor amestecurilor, deoarece prezintă proprietăţi optime care permit utilizarea materialelor obţinute pentru realizarea unor produse 
soles, heels and top-pieces for general use footwear, flexible rubber plates for intermediate soles destined for footwear, boots, hoses and ducts, gaskets, conveyor belts, pressed technical rubber products for cars, etc. cum ar fi: tălpi, tocuri şi partea de sus a pieselor de încălţăminte de uz general, plăci de cauciuc flexibile pentru încălţăminte, cizme, furtunuri şi conducte, garnituri, curele pentru benzi transportoare, piese din cauciuc presat pentru automobile etc.

Table 1: Hardness, elasticity, $100 \%$ elastic modulus and tensile strength of EPDM/HDPE samples, vulcanized by EB irradiation

Tabelul 1: Duritatea, elasticitatea, modulul 100\% şi rezistenţa la rupere a probelor de EPDM/HDPE vulcanizate prin iradiere cu EA

\begin{tabular}{|c|c|c|c|c|c|}
\hline $\begin{array}{l}\text { Mixture symbol/ } \\
\text { Irradiation dose } \\
\text { Simbol amested/ } \\
\text { Doza de iradiere }\end{array}$ & 0 & 50 kGy & 100 kGy & $150 \mathrm{kGy}$ & 200 kGy \\
\hline \multicolumn{6}{|c|}{$\begin{array}{c}\text { Hardness, }{ }^{\circ} \mathrm{Sh} A \\
\text { Duritate, }{ }^{\circ} \mathrm{Sh} A\end{array}$} \\
\hline $\mathrm{T}_{25} \mathrm{O}$ & 97 & 95 & 96 & 97 & 98 \\
\hline $\mathrm{T}_{50} \mathrm{O}$ & 95 & 95 & 95 & 96 & 95 \\
\hline $\mathrm{T}_{75} \mathrm{O}$ & 88 & 86 & 86 & 90 & 89 \\
\hline $\mathrm{T}_{100} \mathrm{O}$ & 62 & 60 & 61 & 60 & 61 \\
\hline \multicolumn{6}{|c|}{$\begin{array}{l}\text { Elasticity, \% } \\
\text { Elasticitate, \% }\end{array}$} \\
\hline $\mathrm{T}_{25} \mathrm{O}$ & 26 & 22 & 23 & 22 & 23 \\
\hline $\mathrm{T}_{50} \mathrm{O}$ & 28 & 36 & 38 & 38 & 40 \\
\hline $\mathrm{T}_{75} \mathrm{O}$ & 36 & 42 & 40 & 39 & 40 \\
\hline $\mathrm{T}_{100} \mathrm{O}$ & 42 & 48 & 44 & 45 & 44 \\
\hline \multicolumn{6}{|c|}{$\begin{array}{l}100 \% \text { elastic modulus, } \mathrm{N} / \mathrm{mm}^{2} \\
\text { Modul } 100 \%, \mathrm{~N} / \mathrm{mm}^{2}\end{array}$} \\
\hline $\mathrm{T}_{25} \mathrm{O}$ & - & 22.3 & 22.4 & 23 & 22.4 \\
\hline $\mathrm{T}_{50} \mathrm{O}$ & 10.1 & 10.2 & 11.2 & 11.2 & 11.3 \\
\hline $\mathrm{T}_{75} \mathrm{O}$ & 4.4 & 4.7 & 5 & 5.3 & 5.8 \\
\hline $\mathrm{T}_{100} \mathrm{O}$ & 1.4 & 1.4 & 1.5 & 1.5 & 1.5 \\
\hline \multicolumn{6}{|c|}{$\begin{array}{c}\text { Tensile strength, } \mathrm{N} / \mathrm{mm}^{2} \\
\text { Rezistenţa la rupere, } \mathrm{N} / \mathrm{mm}^{2}\end{array}$} \\
\hline $\mathrm{T}_{25} \mathrm{O}$ & 22.6 & 22.3 & 22.4 & 23 & 22.4 \\
\hline $\mathrm{T}_{50} \mathrm{O}$ & 10.4 & 11.1 & 11.4 & 11.3 & 11.9 \\
\hline $\mathrm{T}_{75} \mathrm{O}$ & 8.1 & 7.1 & 6.5 & 6.1 & 6.7 \\
\hline $\mathrm{T}_{100} \mathrm{O}$ & 4.4 & 3.8 & 2.3 & 1.8 & 2.4 \\
\hline
\end{tabular}




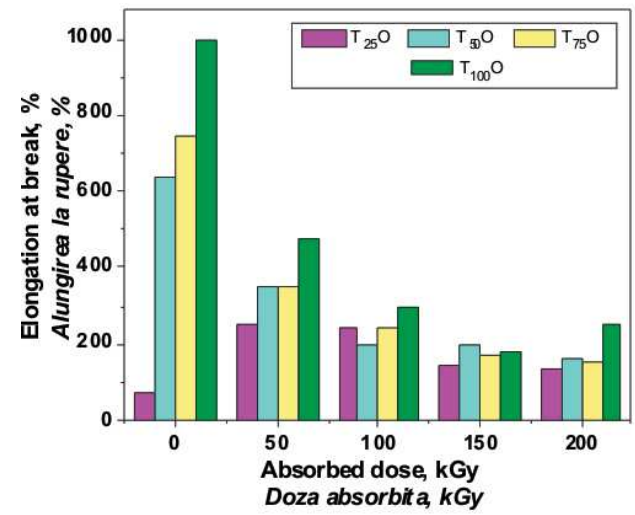

Figure 3. The EB effect on elongation at break Figura 3. Efectul EA asupra alungirii la rupere

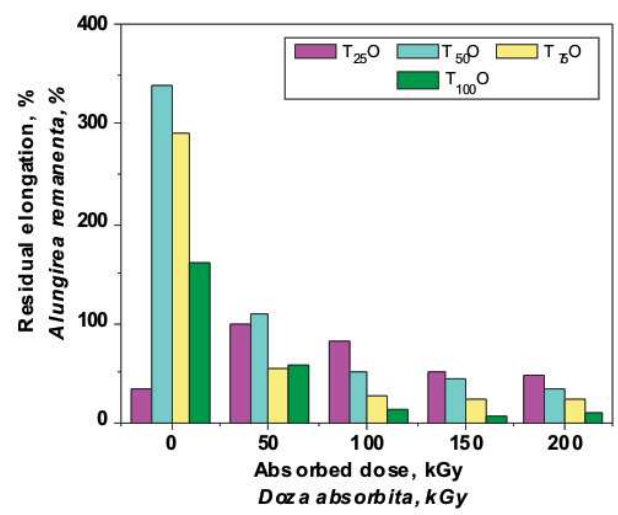

Figure 4. The EB effect on residual elongation Figura 4. Efectul EA asupra alungirii remanente

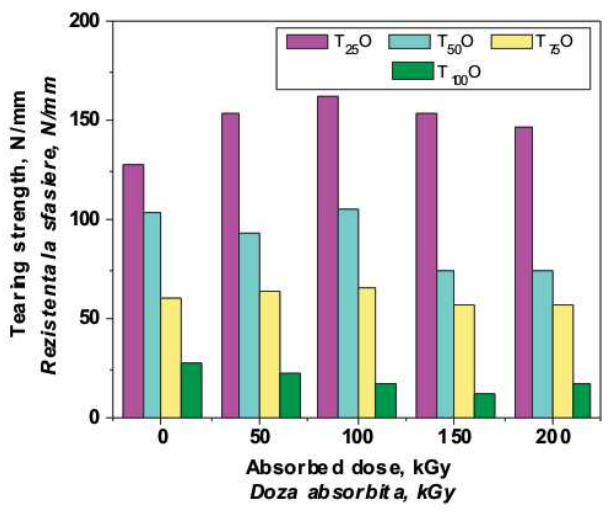

Figure 5. The EB effect on tearing strength

Figura 5. Efectul EA asupra rezistenţei la sfâşiere

The Influence of EB Irradiation Dose on PhysicoMechanical Characteristics of EPDM/HDPE/TMPT and EPDM/HDPE/ZDA Blends

Polyfunctional monomers are effective on modification of polymer material by crosslinking. Generally speaking, there are two factors which affect the functionality of polyfunctional monomers in the polymer: one is the unsaturation of polyfunctional monomers and the other is the solubility of polyfunctional monomers in the polymer [10]. The polyfunctional monomers are coagents and can participate in a number of radical reaction mechanisms, including grafting and radical addition [11-14]. These polyfunctional monomers can be grouped according to their influence on cure kinetics and ultimate physical-mechanical properties. Type I polyfunctional monomers are highly reactive and increase both the rate and state of cure (acrylate,
Influenţa dozei de EA asupra caracteristicilor fizicomecanice ale amestecurilor EPDM/HDPE/TMPT şi EPDM/HDPE/ZDA

Monomerii polifuncţionali sunt eficienţi pentru modificarea materialelor polimerice prin reticulare. În general, există doi factori care afectează funcţionalitatea monomerilor polifuncţionali în polimer: unul este nesaturarea monomerilor polifuncţionali, iar celălalt este solubilitatea acestora în polimer [10]. Monomerii polifuncţionali sunt coagenţi şi pot participa într-o serie de mecanisme de reacţii radicalice, inclusiv grefare şi adiţie radicali [11-14]. Aceşti monomeri polifuncţionali pot fi grupaţi în funcţie de influenţa lor asupra cineticii de reacţie şi, în final, asupra proprietăţilor fizicomecanice. Monomerii polifuncţionali de tipul I sunt puternic reactivi şi contribuie atât la creşterea randamentului de reacţie, cât şi la îmbunătăţirea caracteristicilor materialului reticulat (acrilat, 
methacrylate, or maleimide functionality). Type II polyfunctional monomers are based on allyl reactive sites and increase the state of cure only. Monomeric forms include allyl-containing cyanurates, isocyanurates and phthalates [11-14]. In our study we used, as polyfunctional monomers, TMPT (trimethylopropane trimethacrylate) and ZDA (zinc-diacrylate) of type I but with 2 and 3 functionality, respectively (Figure 6).

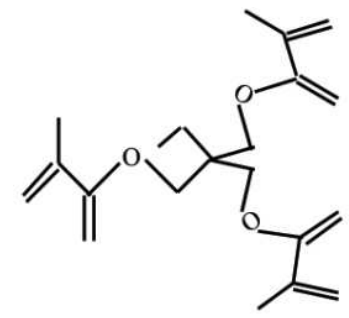

TMPT, trimethylopropane trimethacrylate TMPT, trimetilpropan trimetacrilat metacrilat sau maleimide). Monomerii funcţionali de tip II sunt pe bază de grupări alil reactive şi contribuie numai la îmbunătăţirea caracteristicilor materialului reticulat. Formele monomerice care conţin grupări alilice sunt cianuraţi, izocianuraţi şi ftalaţi [11-14]. În studiul nostru am utilizat monomeri polifuncţionali de tipul I, TMPT (trimetilpropan trimetacrilat) şi ZDA (zinc diacrilat), având însă funcţionalităţi diferite, 2, respectiv 3 (Figura 6).<smiles>C=CC(=O)[OH+][TeH+]</smiles>

ZDA, zinc-diacrylate ZDA, zinc-diacrilat

Figure 6. Chemical structure of the polyfunctional monomers used

Figura 6. Structura chimică a monomerilor polifuncţionali utilizaţi

Tables 2-3 and Figures 7-12 present the physicomechanical properties of EPDM/HDPE/TMPT and EPDM/HDPE/ZDA blends for different compositions and irradiation doses.
În Tabelele 2-3 şi Figurile 7-12 sunt prezentate caracteristicile fizico-mecanice ale amestecurilor EPDM/HDPE/TMPT şi EPDM/HDPE/ZDA pentru diferite compoziţii şi doze de iradiere.

Table 2: Hardness, elasticity, $100 \%$ elastic modulus

and tensile strength of EPDM/HDPE/TMPT samples, vulcanized by EB irradiation

Tabelul 2: Duritatea, elasticitatea, modulul 100\%

şi rezistenţa la rupere a probelor de EPDM/HDPE/TMPT vulcanizate prin iradiere cu EA

\begin{tabular}{|c|c|c|c|c|}
\hline $\begin{array}{l}\text { Mixture symbol/ } \\
\text { Irradiation dose } \\
\text { Simbol amestec/ } \\
\text { Doza de iradiere }\end{array}$ & 50 kGy & 100 kGy & 150 kGy & 200 kGy \\
\hline \multicolumn{5}{|c|}{$\begin{array}{l}\text { Hardness, ' } \mathrm{ShA} \\
\text { Duritate, }{ }^{\circ} \mathrm{Sh} A\end{array}$} \\
\hline $\mathrm{T}_{25} \mathrm{OT}_{3}$ & 98 & 98 & 98 & 98 \\
\hline $\mathrm{T}_{25} \mathrm{OT}_{6}$ & 98 & 97 & 97 & 97 \\
\hline $\mathrm{T}_{25} \mathrm{OT}_{9}$ & 99 & 99 & 99 & 98 \\
\hline $\mathrm{T}_{25} \mathrm{OT}_{12}$ & 99 & 99 & 98 & 99 \\
\hline \multicolumn{5}{|c|}{$\begin{array}{l}\text { Elasticity, \% } \\
\text { Elasticitate, \% }\end{array}$} \\
\hline $\mathrm{T}_{25} \mathrm{OT}_{3}$ & 18 & 22 & 24 & 24 \\
\hline $\mathrm{T}_{25} \mathrm{OT}_{6}$ & 24 & 25 & 24 & 26 \\
\hline $\mathrm{T}_{25} \mathrm{OT}_{9}$ & 24 & 25 & 26 & 22 \\
\hline $\mathrm{T}_{25} \mathrm{OT}_{12}$ & 24 & 26 & 24 & 22 \\
\hline
\end{tabular}


Table 2: Continued

Tabelul 2: Continuare

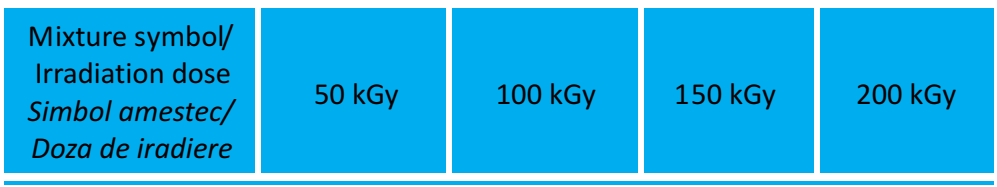

\begin{tabular}{|c|c|c|c|c|}
\hline \multicolumn{5}{|c|}{$\begin{array}{c}100 \% \text { elastic modulus, } \mathrm{N} / \mathrm{mm}^{2} \\
\text { Modul } 100 \%, \mathrm{~N} / \mathrm{mm}^{2}\end{array}$} \\
\hline $\mathrm{T}_{25} \mathrm{OT}_{3}$ & 21.8 & - & 22.7 & 23.5 \\
\hline $\mathrm{T}_{25} \mathrm{OT}_{6}$ & 21.4 & 23.1 & 23.1 & 23.2 \\
\hline $\mathrm{T}_{25} \mathrm{OT}_{9}$ & 20.7 & 21.6 & 21.8 & 22.4 \\
\hline $\mathrm{T}_{25} \mathrm{OT}_{12}$ & 22.2 & 22.5 & - & - \\
\hline
\end{tabular}

Tensile strength, $\mathrm{N} / \mathrm{mm}^{2}$ Rezistenţa la rupere, $\mathrm{N} / \mathrm{mm}^{2}$

\begin{tabular}{|c|c|c|c|c|}
\hline $\mathrm{T}_{25} \mathrm{OT}_{3}$ & 21.8 & 22.3 & 22.7 & 23.5 \\
\hline $\mathrm{T}_{25} \mathrm{OT}_{6}$ & 21.4 & 23.1 & 23.3 & 25.8 \\
\hline $\mathrm{T}_{25} \mathrm{OT}_{9}$ & 20.7 & 21.6 & 21.8 & 22.4 \\
\hline $\mathrm{T}_{25} \mathrm{OT}_{12}$ & 22.2 & 22.5 & 23 & 25.7 \\
\hline
\end{tabular}

Table 3: Hardness, elasticity, $100 \%$ elastic modulus and tensile strength of EPDM/HDPE/ZDA samples vulcanized by EB irradiation

Tabelul 3: Duritatea, elasticitatea, modulul 100\% şi rezistenţa la rupere a probelor de EPDM/HDPE/ZDA vulcanizate prin iradiere cu EA

\begin{tabular}{|c|c|c|c|c|}
\hline $\begin{array}{l}\text { Mixture symbol/ } \\
\text { Irradiation dose } \\
\text { Simbol amestec/ } \\
\text { Doza de iradiere }\end{array}$ & 50 kGy & 100 kGy & 150 kGy & 200 kGy \\
\hline \multicolumn{5}{|c|}{$\begin{array}{c}\text { Hardness, }{ }^{\circ} \mathrm{ShA} \\
\text { Duritate, }{ }^{\circ} \mathrm{Sh} A\end{array}$} \\
\hline $\mathrm{T}_{25} \mathrm{OZ}_{3}$ & 98 & 97 & 98 & 98 \\
\hline $\mathrm{T}_{25} \mathrm{OZ}_{6}$ & 97 & 97 & 98 & 97 \\
\hline $\mathrm{T}_{25} \mathrm{OZ}_{9}$ & 98 & 98 & 98 & 98 \\
\hline $\mathrm{T}_{25} \mathrm{OZ}_{12}$ & 97 & 98 & 98 & 98 \\
\hline \multicolumn{5}{|c|}{$\begin{array}{l}\text { Elasticity, \% } \\
\text { Elasticitate, \% }\end{array}$} \\
\hline $\mathrm{T}_{25} \mathrm{OZ}_{3}$ & 26 & 26 & 26 & 24 \\
\hline $\mathrm{T}_{25} \mathrm{OZ}_{6}$ & 24 & 24 & 25 & 26 \\
\hline $\mathrm{T}_{25} \mathrm{OZ}_{9}$ & 22 & 23 & 24 & 24 \\
\hline $\mathrm{T}_{25} \mathrm{OZ}_{12}$ & 24 & 25 & 26 & 24 \\
\hline \multicolumn{5}{|c|}{$\begin{array}{l}100 \% \text { elastic modulus, } \mathrm{N} / \mathrm{mm}^{2} \\
\text { Modul } 100 \%, \mathrm{~N} / \mathrm{mm}^{2}\end{array}$} \\
\hline $\mathrm{T}_{25} \mathrm{OZ}_{3}$ & 22 & 21.6 & 21.9 & 23.4 \\
\hline $\mathrm{T}_{25} \mathrm{OZ}_{6}$ & - & 22 & 22.3 & 22.8 \\
\hline $\mathrm{T}_{25} \mathrm{OZ}_{9}$ & 21.7 & 22.4 & 22.8 & 23 \\
\hline $\mathrm{T}_{25} \mathrm{OZ}_{12}$ & 19.8 & 20.6 & 23.7 & 24.5 \\
\hline
\end{tabular}


Table 3: Continued

Tabelul 3: Continuare

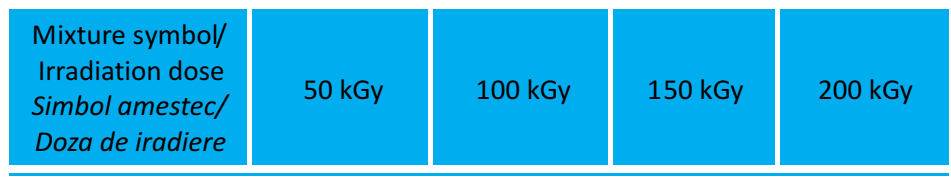

\begin{tabular}{|c|c|c|c|c|}
\hline \multicolumn{5}{c}{$\begin{array}{c}\text { Tensile strength, } \mathrm{N} / \mathrm{mm}^{2} \\
\text { Rezistenta la rupere, } \mathrm{N} / \mathrm{mm}^{2}\end{array}$} \\
\hline $\mathrm{T}_{25} \mathrm{OZ}_{3}$ & 22 & 22 & 24.1 & 25.2 \\
\hline $\mathrm{T}_{25} \mathrm{OZ}_{6}$ & 22.5 & 22.7 & 22.9 & 23.2 \\
\hline $\mathrm{T}_{25} \mathrm{OZ}_{9}$ & 21.7 & 22.4 & 22.8 & 23 \\
\hline $\mathrm{T}_{25} \mathrm{OZ}_{12}$ & 19.8 & 20.6 & 23.7 & 24.5 \\
\hline
\end{tabular}

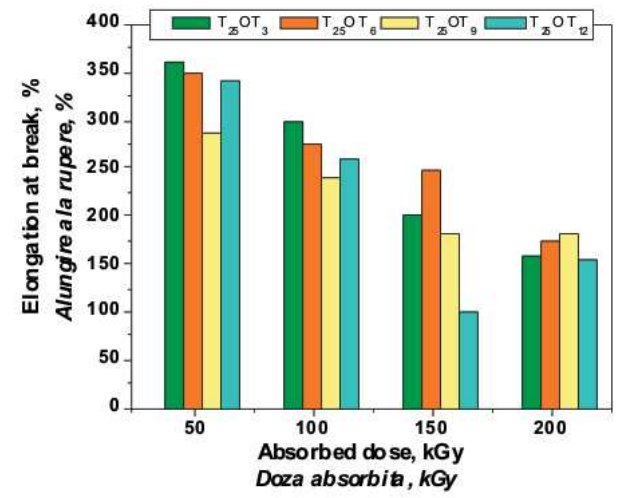

Figure 7. The EB effect on elongation at break of EPDM/HDPE/TMPT samples

Figura 7. Efectul EA asupra alungirii la rupere a probelor de EPDM/HDPE/TMPT

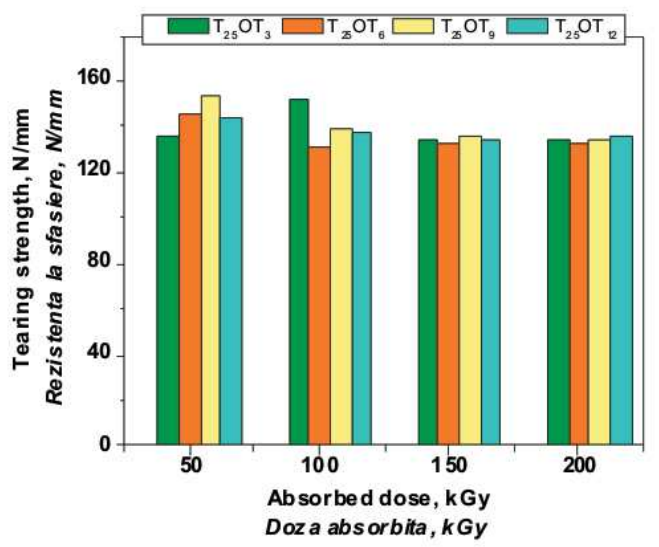

Figure 9. The EB effect on tearing strength of EPDM/HDPE/TMPT samples

Figura 9. Efectul EA asupra rezistenţei la sfâşiere a probelor de EPDM/HDPE/TMPT

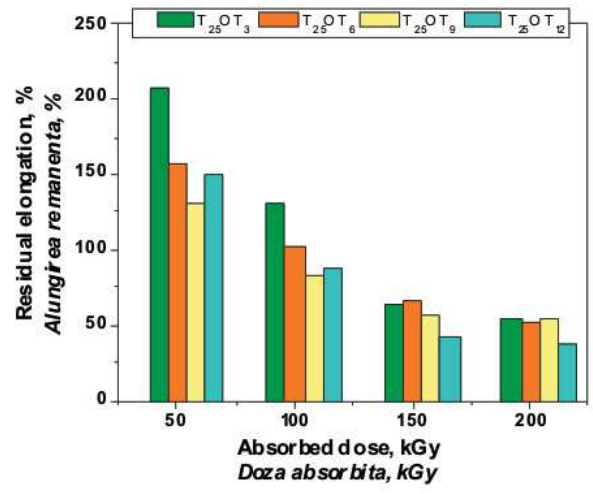

Figure 8. The EB effect on residual elongation of EPDM/HDPE/TMPT samples

Figura 8. Efectul EA asupra alungirii remanente a probelor de EPDM/HDPE/TMPT

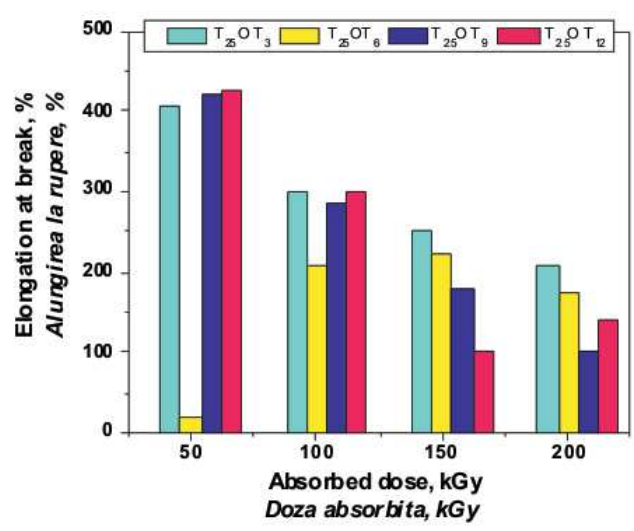

Figure 10. The EB effect on elongation at break of EPDM/HDPE/ZDA samples

Figura 10. Efectul EA asupra alungirii la rupere a probelor de EPDM/HDPE/ZDA 


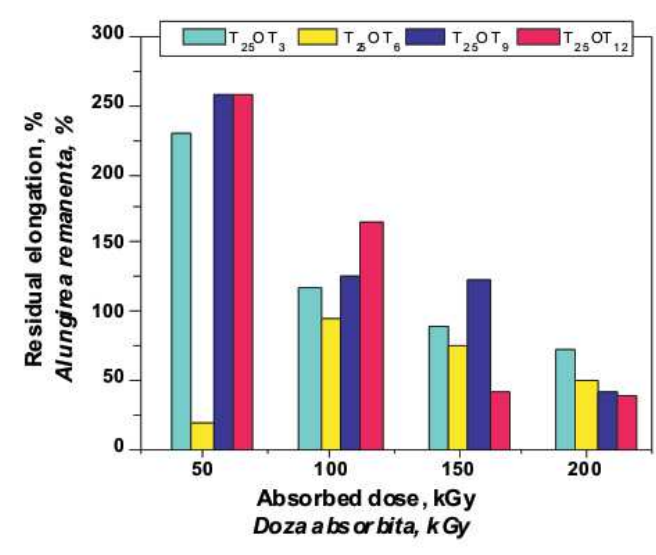

Figure 11. The EB effect on residual elongation of EPDM/HDPE/ZDA samples

Figura 11. Efectul EA asupra alungirii remanente a probelor de EPDM/HDPE/ZDA

PFMs are used in the polymeric material in order to reduce the irradiation dose for crosslinking [15, 16]. They interact with the polymer and produces a network structure at a smaller irradiation dose because of their higher reactivity $[15,17]$. This network structure is responsible for the improvement of physico-mechanical characteristics. The analysis of physical and mechanical characteristics of the samples without PFMs (Table 1 and Figures 3-5) and those with 3-12 phr TMPT and ZDA (Tables 2-3 and Figures 7-12) shows an increase of hardness by $1-4{ }^{\circ} \mathrm{Sh}$ $A$ and elasticity by about $9-20 \%$ after the introduction of PFMs, as a consequence of increasing the degree of crosslinking of the mixture. $100 \%$ elastic modulus and tensile strength also showed increases compared to the situation in which PFMs were not used. All these changes were correlated with increasing irradiation dose. Figures 7-12 show how the elongation at break, residual elongation and tearing strength have changed depending on absorbed dose and polyfunctional monomer type. These physicomechanical characteristics present significant changes depending on absorbed dose and/or PFMs concentrations. For all samples, elongation at break and residual elongation decreases with the increase of EB absorbed dose. This decrease that occurs with the increase of absorbed dose indicates that the

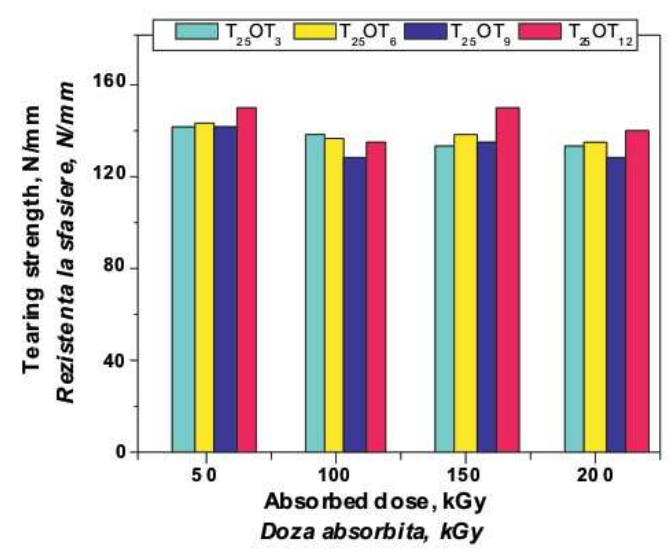

Figure 12. The EB effect on tearing strength of EPDM/HDPE/ZDA samples

Figura 12. Efectul EA asupra rezistenţei la sfâşiere a probelor de EPDM/HDPE/ZDA

Monomerii polifunç̧ionali sunt utilizaţi pentru a reduce doza de iradiere utilizată pentru procesul de reticulare $[15,16]$. Aceştia interacţionează cu polimerul, producând o structură de tip reţea la doze mici de iradiere datorită reactivităţii ridicate $[15,17]$. Apariţia acestei structuri de tip reţea este responsabilă pentru îmbunătăţirea caracteristicilor fizico-mecanice. Din analiza caracteristicilor fizico-mecanice ale probelor fără monomer polifuncţional (Tabelul 1 şi Figurile 3-5) şi a celor cu 3-12 phr TMPT şi ZDA (Tabelele 2-3 şi Figurile 7-12), se observă o creştere de 1-4 ºh A a durităţii şi cu aproximativ 9-20\% a elasticităţii după introducerea monomerului polifuncţional, ca o consecinţă a creşterii gradului de reticulare a amestecului. Modulul $100 \%$ şi rezistenţa la rupere au prezentat, de asemenea, creşteri faţă de situaţia în care nu s-au utilizat monomeri polifuncţionali. Toate aceste modificări au fost corelate şi cu creşterea dozei de iradiere. Figurile 7-12 arată felul în care s-au modificat alungirea la rupere, alungirea remanentă şi rezistenţa la sfâşiere în funcţie de doza absorbită şi tipul monomerului polifunç̧ional. Aceste caracteristici fizico-mecanice prezintă modificări semnificative în funcţie de doza absorbită şi/sau concentrată de MPF. Pentru toate probele, alungirea la rupere şi alungirea remanentă scad odată cu creşterea dozei de EA absorbite. Această scădere care apare odată cu creşterea dozei absorbite indică faptul că structura de 
network structure of the crosslinked rubbers becomes tighter and less flexible, so that molecular movements are restricted. The elongation at break and residual elongation are affected by PFMs functionality. Thus, their values obtained by the characterization of mixtures in which bifunctional monomer was used are lower than those obtained in the case of using trifunctional monomer. Tearing strength shows a maximum point around $50 \mathrm{kGy}$, after that showing a slight decrease. The displacement of maximum point specific for mixtures without PFMs from about $10 \mathrm{kGy}$ to smaller EB doses, indicate the PFMs efficiency in lowering the irradiation dose which is required for cross-linking.

\section{CONCLUSIONS}

By electron beam irradiation of EPDM/HDPE blends in the presence of polyfunctional monomers, new materials with improved physico-mecanical characteristics have been obtained as a result of crosslinking reactions. It was observed that the physico-mechanical properties undergo significant changes depending on the irradiation dose and/or polyfunctional monomer concentration. Introduction of polyfunctional monomers helps lower the optimal electron beam irradiation dose. reţea a cauciucului reticulat devine mai strânsă şi mai puţin flexibilă, astfel încât mişcările moleculare sunt restricţionate. Alungirea la rupere şi alungirea remanentă sunt afectare de funcţionalitatea monomerului polifuncţional. Astfel, valorile acestora obţinute prin caracterizarea amestecurilor în care s-a utilizat monomer bifuncţional sunt mai scăzute decât cele obţinute în cazul utilizării monomerului trifunç̧ional. Rezistenţa la sfâşiere prezintă un punct de maxim în jurul dozei de 50 kGy, după care prezintă o uşoară scădere. Deplasarea punctului de maxim specific amestecurilor fără MPF de la cca 10 Mrad la valori ale dozei ale EA mai mici, indică eficienţa MPF în scăderea dozei de iradiere necesară reticularii.

\section{CONCLUZII}

Prin iradierea cu electroni acceleraţi a amestecurilor de EPDM/HDPE în prezenţa monomerilor polifuncţionali, ca urmare a reacţiilor de reticulare, se obţin noi materiale cu caracteristici fizicomecanice îmbunătăţite. S-a observat că proprietăţile fizico-mecanice au suferit modificări semnificative în funcţie de doza de iradiere şi/sau concentraţia de monomer polifuncţional. Introducerea monomerilor polifuncţionali ajută la scăderea dozei optime de iradiere cu electroni acceleraţi.

\section{REFERENCES}

1. Stelescu, M.D., Airinei, A., Homocianu, M., , N., Timpu, D., Aflori, M., Polymer Testing, 2013, 32, 2, 187-196.

2. Bhowmick, A.K., Vijayabaskar, V., Rubb. Chem. Technol., 2006, 79, 3, 402-428.

3. Stelescu, M.D., Gurau, D., Craciun, G., Manaila, E., Revista de Pielarie Incaltaminte (Leather and Footwear Journal), 2013, 13, 2, 111-124.

4. Stelescu, M.D., Manaila, E., Proceedings of II International Leather Engineering Congress "Innovative Aspects for Leather Industry", Izmir, Turkey, May 12-13, 2011, 311-316.

5. Jinhua, W., Yoshii, F., Makuuchi, K., Radiat. Phys. Chem., 2001, 60, 1-2, 139-142.

6. Stelescu, M.D., Manaila, E., Craciun, G., J. Appl. Polym. Sci., 2013, 128, 4, 2325-2336.

7. Odian, G., Bernstein, B.S., J. Polym. Sci. A, 1964, 2, 6, 2835-2848.

8. Chantara, T.R., Nasir, M., Baharin, A., Khairul, Z., Nucl. Instrum. Methods Phys. Res. B, 2000, 171, 4, 455-464.

9. Sharif, J., Aziz, S.H.S.A., Hasim, K., Radiat. Phys. Chem., 2000, 58, 2, 191-195. 
10. Tawney, P.O., Wenisch, W.J., van der Burg, S., Relyea, D.I., J. Appl. Polym., 1964, 8, 5, 2281-2298.

11. Alvarez-Grima, M.M., PhD Thesis - Novel Co-agents for Improved Properties in Peroxide Cure of Saturated Elastomers, Printed by Print Partners Ipskamp, ISBN: 90-365-2456-3, Enschede, Netherlands, 2007, 11-25.

12. Tuccio, A., Rubber World, 1994, 209, 5, 34-37.

13. Stelescu, M.D., Manaila, E., Zuga, N., Polym. J., 2011, 43, 9, 792-800.

14. Stelescu, M.D., Manaila, E., Craciun, G., Zuga, N., Polym. Bull., 2012, 68, 1, 263-285.

15. Yasin, T., Ahmed, S., Ahmed, M., Yoshii, F., Radiat. Phys. Chem., 2005, 73, 3, 155-158.

16. Ahmed, S., Ruimin, Z., IAEA TECDOC-1062, 1999, 129-139.

17. Makuuchi, K., Hagiwara, M., J. Appl. Polym. Sci., 1984, 29, 965-976. 